\title{
PENERAPAN PEMBELAJARAN MATEMATIKA BERBANTUAN VIDEO TUTORIAL UNTUK MENINGKATKAN MINAT DAN PRESTASI BELAJAR MATEMATIKA SISWA KELAS VIIID SMP NEGERI 2 SAWAN
}

\author{
I Putu Agus Dipa Prayatna, I Gusti Putu Sudiarta, I Nyoman Gita \\ Jurusan Pendidikan Matematika Universitas Pendidikan Ganesha \\ Singaraja, Indonesia \\ e-mail: dipa.prayatna11@gmail.com,gussudiarta@yahoo.de,inyomangita@gmail.com
}

\begin{abstract}
Abstrak
Penelitian ini bertujuan untuk meningkatkan minat dan prestasi bealajar matematika siswa Kelas VIIID SMP Negeri 2 Sawan setelah diterapkan pembelajaran matematika berbantuan video tutorial. Jenis penelitian ini adalah penelitian tindakan kelas (PTK) yang melibatkan subjek seluruh siswa kelas VIIID SMP Negeri 2 Sawan pada semester ganjil tahun ajaran 2017/2018. Penelitian ini dilaksanakan dalam tiga siklus, di mana masing-masing siklus terdiri atas tahap perencanaan, pelaksanaan tindakan, observasi dan evaluasi, serta refleksi. Data minat belajar siswa dikumpulkan dengan menggunakan angket dan data prestasi belajar siswa menggunakan tes berbentuk uraian. Data yang telah terkumpul selanjutnya dianalisis secara deskriptif. Hasil penelitian menunjukkan bahwa rata-rata skor minat belajar siswa mengalami peningkatan. Rata-rata skor minat belajar siswa dari 51,67 (kategori cukup positif) pada refleksi awal mengalami peningkatan menjadi 59,28 (kategori positif) pada siklus I, 64,71 (kategori sangat positif) pada siklus II, dan 66,53 (kategori sangat positif) pada siklus III. Rata - rata skor minat belajar siswa pada siklus III berada pada kategori sangat positif. Untuk prestasi belajar matematika rata-rata skor prestasi belajar siswa dari 27,54 pada refleksi awal mengalami peningkatan menjadi 61,93 pada siklus I, 69,67 pada siklus II, dan 77,66 pada siklus III. Ini menunjukkan bahwa prestasi belajar siswa sudah memenuhi indikator keberhasilan, yaitu pada siklus III skor siswa memenuhi minimal KKM 70 dan $75 \%$ siswa berada pada kategori tuntas. Peningkatan minat dan prestasi belajar siswa kelas VIIID SMP Negeri 2 Sawan terjadi karena siswa sudah mampu mengikuti setiap tahapan pembelajaran dengan menggunakan video tutorial. Selain itu, proses belajar siswa terhadap penerapan pembelajaran berbantuan video tutorial dalam setiap pertemuan mengalami peningkatan. Berdasarkan hasil penelitian ini, dapat disimpulkan bahwa penerapan pembelajaran matematika berbantuan video tutorial dapat meningkatkan minat dan prestasi belajar siswa kelas VIIID SMP Negeri 2 Sawan.
\end{abstract}

Kata kunci: Video Tutorial, Minat Belajar, Prestasi Belajar

\begin{abstract}
This study aims to increase interest and achievement of math student learning Class VIIID SMP Negeri 2 Sawan after applied learning mathematics assisted video tutorial. The type of this research is classroom action research (PTK) which involves subject of all students of class VIIID SMP Negeri 2 Sawan in odd semester of academic year 2017/2018. This research was conducted in three cycles, each cycle consisting of planning, implementation, observation and evaluation, and reflection. Student interest data were collected by using questionnaire and student achievement data using blinded test. The data that has been collected is then analyzed descriptively. The results showed that the average score of student learning interest has increased. The average score of student learning interest from 51,67 (positive enough category) on the initial reflection increased to 59.28 (positive category) in cycle I, 64,71 (very positive category) in cycle II, and 66,53 (category very positive) in cycle III. The average score of student learning interest in cycle III is in very positive category. For
\end{abstract}


the achievement of learning mathematics average score of student achievement from 27.54 at initial reflection increased to 61,93 in cycle I, 69,67 in cycle II, and 77,66 in cycle III. This shows that student achievement has fulfilled the indicator of success, that is in cycle III students score fulfill the minimum KKM 70 and $75 \%$ of students are in complete category. Increasing the interest and achievement of students of class VIIID SMP Negeri 2 Sawan occurred because students have been able to follow every stage of learning by using video tutorial. In addition, the student learning process on the application of tutorial video tutorial learning in each meeting has increased. Based on the results of this study, it can be concluded that the application of tutorial-assisted mathematics learning videos can increase interest and achievement of students of class VIIID SMP Negeri 2 Sawan.

Keywords: Video Tutorial, Interest Learning, Learning Achievement

\section{PENDAHULUAN}

Pendidikan adalah proses pengubahan sikap dan perilaku seseorang atau kelompok orang dalam usaha mendewasakan manusia melalui upaya pengajaran dan pelatihan. "Pendidikan merupakan hal yang penting dan wajib ditempuh oleh siapa saja" (Depdiknas. 2008: 326). Sebagaimana yang tercantum dalam Undang-Undang Nomor 20 Tahun 2003 tentang Sistem Pendidikan Nasional, Pasal 1 ayat 1 menyatakan bahwa pendidikan adalah usaha sadar dan terencana untuk mewujudkan suasana belajar dan proses pembelajaran agar peserta didik secara aktif mengembangkan potensi dirinya untuk memiliki kekuatan spiritual keagamaan, pengendalian diri, kepribadian, kecerdasan, akhlak mulia, serta keterampilan yang diperlukan dirinya, masyarakat, bangsa dan negara. Proses belajar diselenggarakan secara formal di sekolah-sekolah, tidak lain dimaksudkan untuk mengarahkan perubahan pada diri siswa secara terencana baik dalam aspek pengetahuan, keterampilan, maupun sikap. Melalui pendidikan diharapkan segala potensi yang dimiliki oleh setiap individu akan berkembang dan mampu bersaing dengan perkembangan zaman baik ilmu maupun teknologi. Menurut Dantes (dalam Sudiarta, 2013) menngemukakan bahwa pembelajaran pada hakekatnya merupakan inti dari proses secara keseluruhan. Oleh karena itu, kualitas suatu bangsa ditentukan oleh mutu pendidikannya.

Faktanya, untuk mencapai kemajuan bangsa, pendidikan masih menjadi suatu masalah. Terlihat dari masih rendahnya mutu pendidikan khususnya di bidang matematika. Banyaknya hal yang bisa diinvestigasi dalam pendidikan Matematika, Sudiarta (2007:828) menyatakan ada empat komponen utama yang harus mendapatkan perhatian, yaitu :

1. Siswa : kedewasaan, kemampuan intelektual, pengalaman masa lalu dan penampilan/performance siswa dalam Matematika, cara belajar, sikap terhadap Matematika, serta penyesuaian sosial siswa.

2. Guru : pemahaman guru terhadap Matematika, kepercayaan baik pada Matematika itu sendiri, maupun pada bagaimana Matematika dipelajari, gaya mengajar dan berinteraksi dengan siswa, pandangan guru pada peran assessment/sistem penilaian, profesionalisme guru, serta keefektivan sebagai guru Matematika.

3. Konten Matematika : keluasan dan pengorganisasiannya ke dalam kurikulum, tingkat kesulitannya, jangkauan serta posisinya dalam tahap-tahap tertentu, pengetahuan yang harus diberikan sebelumnya/pengetahuan prasyarat, serta pembagiannya ke dalam ketrampilan-ketrampilan, konsepkonsep, serta aplikasinya yang kontekstual.

4. Model-model Pedagogis dan Pembelajaran : penggunaan model dan strategi pembelajaran yang optimal, rancangan materi pembelajaran, penggunaan media dan multimedia, alat peraga, strategi 
pengelompokan kelas, pengaruh inovasi pembelajaran, dan asememen alternatif.

Dari keempat kompenen tersebut, model model pedagogis dan pembelajarannya memiliki peranan penting di era globalisasi seperti saat ini dan sangat diperlukan baik untuk kehidupan sehari-hari maupun untuk kemajuan IPTEK. Dalam hal ini, untuk mempelajari matematika diperlukan keinginan yang kuat dari dalam diri siswa. Siswa yang mempunyai minat dan keinginan belajar yang tinggi akan lebih bersemangat dalam kegiatan belajarnya, dengan semangat tinggi serta bersungguh-sungguh dalam belajar, maka prestasi belajar yang diperoleh akan meningkat. Untuk mengoptimalkan minat belajar siswa dalam suatu proses pembelajaran diperlukan inovasi baru dalam mengajar. Salah satu inovasi dalam proses pembelajaran yakni menggunakan media.

Ketersediaan teknologi digital yang cangih telah mengubah cara berfikir tentang matematika dan bagimana pembelajaran matematika yang efektif mestinya dilakukan (Sudiarta, dan Sadra, 2016). Penggunaan media sebagai alat bantu dalam proses pembelajaran sudah mengalami perkembangan yang panjang. "Puncak dari perkembangan media terjadi pada tahun 1990-an dengan munculnya konsep 'educational technologi' atau 'instructional technologi', yang mana proses pembelajaran berbasis teknologi komputer" (Ryandra Asyhar, 2012:3). Hal ini berarti media pembelajaran tidak hanya berfungsi sebagai alat bantu mengajar, melainkan juga sebagai sumber belajar bagi peserta didik. Media audo-visual, adalah jenis media yang digunakan dalam kegiatan pembelajaran dengan melibatkan pendengaran dan penglihatan sekaligus dalam suatu proses atau kegiatan. Pesan dan informasi yang dapat disalurkan melalui media dapat berupa pesan verbal atau nonverbal yang mengandalkan baik penglihatan maupun pendengaran. Beberapa contoh media audio-visual adalah, film, video, program TV. Begitu pentingnya peran media sebagai alat dalam pembelajaran matematika, sehingga sangat perlu untuk dikembangkan agar pembelajaran matematika sesuai dengan tujuan yang diharapkan.

Namun pada kenyataannya, pembelajaran yang menggunakan media pembelajaran sebagai inovasi belajar masih kurang. Hal ini terlihat pada pembelajaran matematika yang dilaksanakan di kelas VIID SMP Negeri 2 Sawan masih belum sesuai dengan yang diharapkan. Terlihat dari permasalahan yang ditemukan pada saat observasi awal yang peneliti laksanakan. Observasi awal yang peneliti lakukan menggunakan beberapa cara, yaitu pengamatan langsung di kelas, wawancara dengan guru dan siswa, angket, dan tes.

Metode pengamatan langsung, wawancara, dan angket digunakan untuk mendapatkan data minat belajar siswa. Dari hasil observasi dengan cara tersebut minat belajar siswa masih kurang karena masih ada siswa yang mengalami permasalahan dalam minat belajar diantaranya sebagai berikut.

1. Ketika pembelajaran berlangsung, sebagian besar siswa cenderung tidak mau membaca buku pelajaran yang ada dan hanya beberapa siswa saja yang mendengarkan penjelasan guru.

2. Masih kurangnya media pembelajaran yang dimiliki sehingga dalam pembelajaran masih terlihat kurang inovatif.

3. Siswa kesulitan dalam menjawab latihan soal yang diberikan karena tidak paham dengan penjelasan ataupun contoh yang diberikan.

Dari tes prestasi yang peneliti berikan kepada siswa siswa hanya $4,17 \%$ yang bisa memenuhi KKM yang ditetapkan dan 95,83\% berada dibawah KKM nilai tertinggi dan nilai terendah yang diperoleh siswa, yaitu 82 dan 5 . Hal ini menunjukkan prestasi belajar siswa perlu ditingkatkan. Setelah dikoreksi peneliti menemukan beberapa siswa yang masih kurang dalam indikator kognitif prestasi belajar berdasarkan tingkat taksonomi Bloom (dalam Arikunto, 2012) baik dari segi pengetahuan, pemahaman, penerapan, analisis, sintesis, dan 
evaluasi. Hal ini berdampak pada kurangnya prestasi belajar yang dimiliki siswa. Hal ini menjadi suatu dasar bagi peneliti bagaimana cara meningkatkan prestasi belajar siswa.

Dari temuan tersebut prestasi belajar siswa masih kurang karena masih banyak kesulitan belajar yang ditemukan pada siswa sebagai berikut.

1. Siswa masih kurang dalam menentukan konsep apa yang digunakan untuk menyelesaikan suatu soal atau permasalahan yang diberikan.

2. Siswa juga masih kurang dalam menentukan model penyelesaian suatu permasalahan.

Berdasarkan kenyataan tersebut, diperlukan sebuah inovasi dalam pembelajaran. Salah satu cara yang dapat dilakukan untuk meningkatkan minat belajar dan hasil belajar matematika siswa dengan menggunakan media pembelajaran yang menarik minat dan mampu menjelaskan cara pengerjaan suatu soal agar siswa menjadi lebih paham sehingga prestasi belajar siswa juga bisa meningkat. Salah satu media pembelajaran yang dapat meningkatkan minat belajar siswa adalah video tutorial.

Video tutorial termasuk dalam kategori media audio visual. Dalam program pembelajaran yang berbantuan video meniru sistem tutor yang dilakukan oleh guru atau instruktur. Informasi atau pesan berupa suatu konsep disajikan dilayar komputer dengan teks, gambar, grafik, atau video. Bahkan video tutorial memiliki kelebihan lain yaitu bisa dibawa pulang, bisa dipelajari kapan saja, atau bisa dipelajari secara online dengan mengunggahnya di youtube, blog, website, dll. Siswa diharapkan telah membaca, menginterpretasi, dan menyerap konsep suatu pertanyaan atau soal yang diberikan. Kemampuan video melukiskan gambar hidup dan suara memberinya daya tarik tersendiri. Video tutorial dapat menyajikan informasi, memaparkan proses, menjelaskan konsep yang rumit, mengajarkan keterampilan, menyingkat atau memperpanjang jam belajar, dan dapat mempengaruhi sikap.
Video tutorial dapat diproduksi untuk menjelaskan secara detail suatu proses tertentu, cara pengerjaan tugas tertentu, cara latihan, dan lain sebagainya yang berguna untuk memudahkan tugas para trainer, instruktur, guru, dosen, manajer. Minat besar pengaruhnya terhadap belajar siswa, karena jika bahan pelajaran yang dipelajari sesuai dengan minat siswa, siswa akan belajar dengan sebaik-baiknya karena pelajaran tersebut memiliki daya tarik baginya. Bahan pelajaran yang menarik minat siswa, lebih mudah dipelajari dan disimpan, karena minat menambah kegiatan belajar. Hal ini akan berpengaruh terhadap prestasi belajar siswa karena minat dan prestasi belajar saling mempengaruhi. Dengan video tutorial diharapkan memberikan solusi terbaik dalam memecahkan masalah yang dihadapi siswa di SMP Negeri 2 Sawan, karena :

1. Video tutorial memberikan inovasi baru dalam proses pembelajaran yang inovatif sehingga siswa tidak jenuh dengan pembelajaran konvensional yang diterapkan.

2. Video tutorial dapat meningkatkan minat belajar siswa karena menggunakan kombinasi visual dan audio yang dapat menarik perhatian siswa saat pembelajaran berlangsung, sehingga siswa menjadi lebih tertarik dalam mengikuti pembelajaran.

3. Video tutorial bisa digunakan sebagai fasilitator lain belajar selain guru, karena video tutorial dapat menggambarkan suatu proses atau menjelaskan suatu proses layaknya guru di kelas.

4. Video tutorial dapat disaksikan secara berulang - ulang jika dipandang perlu dan juga dapat dibawa kemana mana, dipelajari kapan saja baik online maupun offline di luar pembelajaran di kelas sebagai sumber belajar lain.

Berdasarkan uraian di atas, maka penulis melakukan suatu penelitian dalam bentuk penelitian tindakan kelas dengan judul "Penerapan Pembelajaran Matematika Berbantuan Video Tutorial untuk Meningkatkan Minat dan Prestasi 


\section{Belajar Matematika Siswa Kelas VIIID SMP Negeri 2 Sawan"}

\section{METODE}

Penelitian yang dilaksanakan termasuk ke dalam jenis penelitian tindakan kelas (PTK). Langkah PTK : a) perencanaan (planning), b) pelaksanaan (action), c) pengumpulan data (observing), d) penganalisis data/informasi untuk memutuskan sejauh mana kelebihan atau kelemahan tindakan tersebut (reflecting). PTK bercirikan perbaikan terus-menerus sehingga peningkatan menjadi tolak ukur berhasilnya (berhentinya) siklus-siklus tersebut. Penelitian ini ditujukan untuk meningkatkan minat dan prestasi belajar matematika siswa.

Penelitian ini dilaksanakan di SMP Negeri 2 Sawan . Subjek penelitian adalah siswa kelas VIIID SMP Negeri 2 Sawan semester ganjil tahun ajaran 2017/2018. Alasan dilakukannya penelitian di kelas VIIID SMP Negeri 2 Sawan adalah karena di kelas tersebut minat dan prestasi belajar utamanya pada mata pelajaran matematika masih tergolong rendah. Dalam penelitian ini peneliti bekerja sama dengan guru bidang studi matematika kelas VIIID SMP Negeri 2 Sawan untuk menggali penyebab permasalahan yang dihadapi kelas tersebut serta mengambil keputusan terhadap tindakan yang sebaiknya dilakukan untuk mengatasinya.

Prosedur penelitian yang digunakan sesuai dengan prosedur suatu PTK. Penelitian ini dibagi menjadi dua tahap kegiatan, yaitu refleksi awal dan pelaksanaan penelitian dengan setiap siklus terdiri dari empat tahap yaitu: (1) perencanaan tindakan, (2) pelaksanaan tindakan, (3) observasi dan evaluasi, dan (4) refleksi. Kegiatan refleksi awal meliputi penyebaran angket kepada siswa, wawancarai guru dan observasi kelas. Refleksi awal dilaksanakan untuk memperoleh gambaran yang lebih jelas mengenai masalah yang dihadapi di kelas terkait dengan pembelajaran matematika.

Tahap pelaksanaan penelitian, terdiri atas tahap perencanaan, pelaksanaan, observasi dan evuasi, serta refleksi. Pada tahap perencanaan, peneliti menentukan materi yang dibahas selama penelitian, dan menyiapkan alat serta bahan pembelajaran. Setelah dilakukan perencanaan secara menyeluruh, Selanjutnya dilaksanakan tindakan dengan penerapan video tutorial pada pembelajaran matematika. Pada tahap tindakan ini guru melaksanakan rencana pembelajaran yang telah disusun dan direncanakan oleh peneliti sebelumnya, yaitu pembelajaran matematika dengan menggunakan video tutorial. Pada tahap observasi dan evaluasi, peneliti melakukan pengamatan secara langsung terhadap pembelajaran dan menggunakan alat bantu kamera untuk mendokumentasikan foto-foto selama kegiatan berlangsung tanpa mengganggu pelaksanaan pembelajaran. Selain itu, peneliti juga mencatat hal-hal penting yang terjadi selama pemberian tindakan seperti mencatat hambatan-hambatan dan kekurangan-kekurangan yang ditemukan selama pelaksanaan tindakan dan hal-hal positif yang terjadi selama pembelajaran yang dituangkan dalam bentuk jurnal harian. Hasil yang diperoleh dapat dijadikan sebagai umpan balik dalam merancang rencana yang selanjutnya. Evaluasi dilakukan untuk mengetahui hasil dari pelaksanaan tindakan. Evaluasi yang dilakukan meliputi evaluasi terhadap keseluruhan pembelajaran. Selain itu, evaluasi juga digunakan untuk mengetahui peningkatan prestasi belajar matimatika siswa setelah diberikannya tindakan. Sedangkan, pada tahap refleksi, peneliti bersama guru melaksanakan refleksi terhadap hasil yang dicapai selama siklus berlangsung. Sebagai acuannya adalah hasil observasi dan evaluasi pembelajaran. Refleksi dilakukan berdasarkan hasil observasi dan evaluasi yang bertujuan untuk mengidentifikasi hasil tindakan. Sejauh mana hasil yang dicapai, kelemahan serta kendala yang dialami, kemudian didiskusikan dan dicari alternatif pemecahannya. Selanjutnya dirumuskan dalam suatu perbaikanperbaikan tindakan yang akan dilaksanakan pada siklus selanjutnya. Kelebihan-kelebihan dari hasil evaluasi yang diperoleh hendaknya dipertahankan. 
Kekurangan-kekurangan yang diperoleh dari hasil evaluasi tersebut hendaknya diperbaiki pada tindakan selanjutnya, sehingga diperoleh hasil yang lebih baik.

Instrumen dalam penelitian ini berupa tes dan angket. Tes digunakan untuk mengukur penguasaan dan kemampuan para siswa setelah menerima proses pembelajaran dengan video tutorial. Kelebihan tes dalam bentuk uraian adalah mampu memperlihatkan cara berpikir siswa, bagaimana mereka dapat mengekspresikan dan mengaitkan ide matematika yang mereka miliki, kemudian menuliskannya untuk menyelesaikan permasalahan yang diberikan. Penyusunan soal dalam bentuk uraian juga dapat menghindari terjadinya bias dari hasil evaluasi karena jawaban yang diberikan bukan berdasarkan tebaktebakan. Tes ini dilaksanakan pada akhir setiap siklus. Tes prestasi belajar ini digunakan untuk mengetahui kemampuan prestasi belajar siswa selama satu siklus yang digambarkan berupa skor setelah siswa tersebut mengerjakan tes. Sebelum digunakan, tes ini diuji validitas isi dan validitas konstruknya melalui expert judgement. Sedangkan angket yang digunakan untuk mengumpulkan data mengenai minat siswa terhadap penerapan video tutorial pada pembelajaran matematika diberikan kepada siswa pada akhir penelitian. Angket merupakan instrumen pengumpulan data penelitian berupa sejumlah pertanyaan atau pernyataan tertulis yang diberikan kepada responden atau subjek penelitian (Candiasa, 2010a:8). Sebelum digunakan, angket ini diuji validitas isi menggunakan validitas dari Gregory dengan rater (pakar) yaitu dua orang dosen Jurusan Pendidikan Matematika Undiksha.

Sedangkan data minat belajar siswa terhadap penerapan pembelajaran berbantuan video tutorial dikumpulkan melalui angket minat belajar siswa yang terdiri dari 15 pernyataan yang dilakukan pada akhir penelitian. Angket respon siswa menggunakan skala Likert dengan pilihan yaitu Sangat Setuju (SS), Sejutu (S), Kurang Setuju (KS), Tidak Setuju (TS), dan Sangat Tidak Setuju (STS). Adapun kriteria yang digunakan dalam penggolongan respon siswa disajikan pada tabel berikut.

\section{HASIL DAN PEMBAHASAN HASIL}

Berdasarkan hasil penelitian yang sudah dipaparkan sebelumnya, terlihat bahwa prestasi belajar matematika siswa kelas VIIID SMP Negeri 2 Sawan yang ditinjau dari rata-rata skor tes prestasi belajar sudah memenuhi indikator keberhasilan. Hasil penelitian ini menunjukkan bahwa rata-rata skor prestasi belajar pada siklus I adalah 61,93, rata-rata skor pada siklus II adalah 69,67, dan rata-rata skor prestasi belajar siswa pada siklus III adalah 77,66.

Prestasi belajar siswa kelas VIIID SMP Negeri 2 Sawan mengalami peningkatan pada setiap siklus. Peningkatan rata-rata skor prestasi belajar siswa dari refleksi awal sampai siklus III dapat dilihat seberapa besar peningkatan prestasi siswa. Berikut disajikan ringkasan data minat belajar siswa selama penelitian beserta grafik peningkatannya.

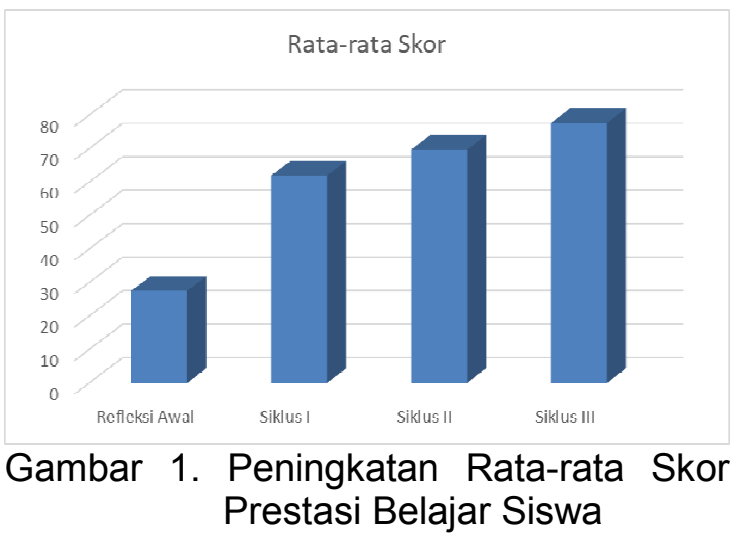

Secara umum, pelaksanaan pembelajaran matematika berbantuan berbantuan video tutorial di kelas VIIID SMP Negeri 2 Sawan sudah berlangsung dengan cukup baik. Namun masih ditemukan beberapa permasalahan-permasalahan yang perlu direfleksi oleh peneliti bersama dengan guru matematika di kelas tersebut. Adapun kendala-kendala yang dihadapi 
pada pelaksanaan tindakan siklus I dapat dijabarkan sebagai berikut.

a. Pembagian media kepada siswa sebelum pembelajaran di kelas masih belum maksimal sehingga masih terdapat siswa yang belum mengetahui bagaimana belajar menggunakan video tutorial yang diberikan.

b. Pada awal pelaksanaan tindakan, siswa masih terlihat kesulitan menyesuaikan diri dengan pembelajaran yang diterapkan yang menuntut siswa lebih aktif dibandingkan kegiatan pembelajaran sebelumnya. Hal tersebut telihat ketika siswa diberikan LKS, beberapa siswa masih enggan untuk mencoba mengerjakan LKS.

c. Untuk siswa yang memiliki kemampuan kurang, siswa masih mengingat kembali media yang dipelajarinya. Bahkan harus bertanya ke teman atau meminjam buku pelajaran untuk mencoba mengingat kembali. Hal ini ditambah dengan fasilitas sekolah yang belum memiliki sarana LCD yang merata di tiap kelas.

d. Siswa masih kesulitan untuk mengkomunikasikan ide-ide matematisnya secara terstruktur. Hal tersebut terlihat ketika siswa disuruh menjawab soal dengan cara yang dipelajari di video tutorial yang diberikan, mereka masih terlihat kurang percaya diri dalam menuliskan jawaban mereka ke papan. Alasannya takut salah. Hal tersebut tentu saja akan berakibat pada kurangnya minat belajar bagi siswa untuk meningkatkan prestasi belajarnya.

Berdasarkan kendala-kendala tersebut, peneliti bersama dengan guru matematika kelas VIIID SMP Negeri 2 Sawan mencari solusi untuk mengatasinya. Adapun solusi untuk mengatasi kendala-kendala tersebut, dijabarkan sebagai berikut.

a. Guru memperbanyak media yang diberikan kepada siswa untuk dipelajari dirumah. Satu bangku mendapatkan satu CD media. Agar siswa tidak berebut mempelajari media tersebut. Selain itu media video tutorial ini tidak hanya dibagikan dengan $C D$, bisa juga menggunakan flashdisk disesuaikan dengan kebutuhan siswa.

b. Guru menarik perhatian dan ketertarikan siswa terhadap materi yang disampaikan dengan selalu mengingatkan betapa pentingnya materi tersebut dan manfaat yang diperoleh siswa dalam keseharian mereka sehingga siswa merasa pembelajaran yang diperoleh menjadi bermakna.

c. Guru melakukan pendeketanpendekatan terhadap siswa yang mempunyai kemampuan rendah dan memberikan motivasi agar mereka berani mencoba mengkomunikasikan baik lisan maupun tulisan, Selain itu guru juga menyediakan LCD dan menayangkan video tutorial dikelas guna memudahkan yang kemampuannya kurang.

d. Guru memberikan motivasi kepada setiap siswa akan pentingnya keberanian dalam menyampaikan gagasan dan memperbanyak latihan soal dengan bantuan video tutorial.

Selanjutnya pada siklus II, pembelajaran pada siklus II sudah berjalan dengan baik, dan terlihat ada peningkatan dari siklus I bila dilihat dari segi kegiatan pembelajaran di kelas maupun dari hasil tindakan. Berdasarkan refleksi yang sudah dilakukan dan dengan memperhatikan hasil yang didapat, terlihat beberapa kemajuan, yaitu :

a. Siswa sudah mulai terbiasa dalam mengikuti pembelajaran sesuai dengan model pembelajaran yang diterapkan, walaupun belum optimal. Hal ini terlihat ketika siswa diberikan LKS, siswa tidak lagi merasa enggan untuk mengerjakan LKS.

b. Siswa mulai tertarik untuk belajar dengan serius dan mau mengerjakan baik LKS maupun menjawab di papan. Siswa mulai percaya diri untuk mengerjakan soal sendiri dengan bantuan video tutorial yang diberikan. Cara menjawab permasalahan yang 
diberikan pun sudah terstruktur dengan baik.

Walaupun sudah menunjukkan beberapa kemajuan, namun masih terdapat beberapa kendala yang dihadapi dalam kegiatan pembelajaran. Adapun kendala-kendala yang dihadapi pada siklus II dapat dijabarkan sebagai berikut.

Pada saat pembelajaran di kelas, beberapa siswa terlihat tidak serius mengerjakan LKS. Hal tersebut terlihat ketika siswa sudah berpasangan, mereka masih asik mengobrol dengan pasangannya. Hal tersebut berakibat pada penggunaan waktu yang tidak efisien.

Bertolak dari beberapa kendala yang dihadapi pada siklus II, kemudian peneliti berdiskusi bersama guru untuk menemukan solusi dalam mengatasi kendala tersebut yang akan dilaksanakan pada siklus III. Upaya yang dilaksanakan pada siklus III pada prinsipnya hampir sama dengan upaya yang dilaksanakan pada siklus II, hanya saja pada siklus III guru lebih banyak memberikan motivasi.

Bertolak dari beberapa kendala yang dihadapi pada siklus II, kemudian peneliti berdiskusi bersama guru untuk menemukan solusi dalam mengatasi kendala tersebut yang akan dilaksanakan pada siklus III. Upaya yang dilaksanakan pada siklus III pada prinsipnya hampir sama dengan upaya yang dilaksanakan pada siklus II, hanya saja pada siklus III guru lebih banyak memberikan motivasi terutama kepada siswa yang mengalami kesulitan selama pembelajaran.

Kemudian pada siklus III, pembelajaran sudah berjalan lebih baik dari siklus-siklus sebelumnya. Adapun beberapa kemajuan selama pelaksanaan tindakan pada siklus III adalah sebagai berikut.

a. Secara umum, pembelajaran sudah berjalan sesuai dengan rencana pelaksanaan pembelajaran yang dibuat yaitu siswa sudah mampu mengikuti setiap tahapan pembelajaran dengan video tutorial, sehingga minat dan prestasi belajar siswa dapat ditingkatkan. b. Siswa sudah mulai serius bekerja dengan bantuan video tutorial, sehingga waktu pembelajaran menjadi lebih efisien.

c. Kondisi kelas ketika pembelajaran berlangsung sudah terlihat lebih kondusif dan siswa pun terlihat antusias serta aktif dalam memberikan jawaban, tanggapan, maupun pertanyaan.

Kemajuan yang ditunjukkan pada setiap siklus, berimplikasi pada skor prestasi belajar siswa yang mengalami peningkatan dari siklus ke siklus seperti yang ditunjukkan pada Gambar 1. Kemajuan tersebut juga tidak lepas dari antusiasme siswa dalam mengikuti pembelajaran matematika. Hal tersebut terlihat dari minat belajar yang ditunjukkan oleh siswa cukup postif. Adapun sebaran minat belajar siswa, ditunjukkan pada gambar berikut.

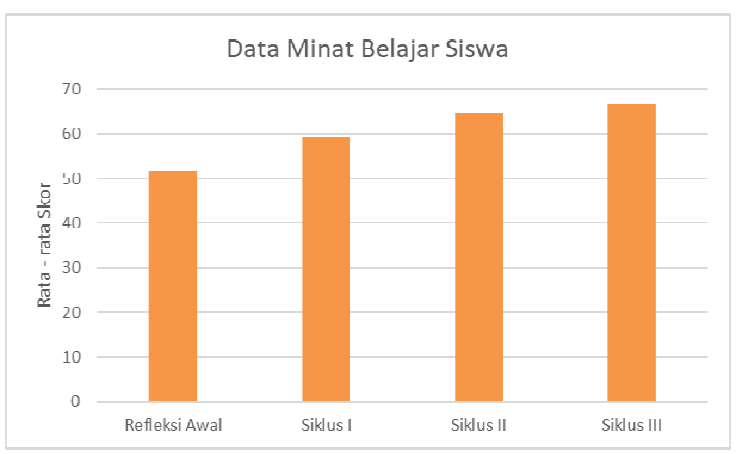

Gambar 2. Sebaran Minat Belajar Siswa

Peningkatan minat dan prestasi belajar di atas di dukung juga dengan adanya peningkatan proses pembelajaran di kelas. Karena proses pembelajaran yang baik tentunya akan meningkatkan minat siswa dalam belajar sehingga prestasi siswa juga meningkat. Peningkatan proses belajar dapat dilihat pada gambar 3. Berikut adalah grafik peningkatan proses belajar matematika siswa setiap pertemuan yang dilaksanakan. 


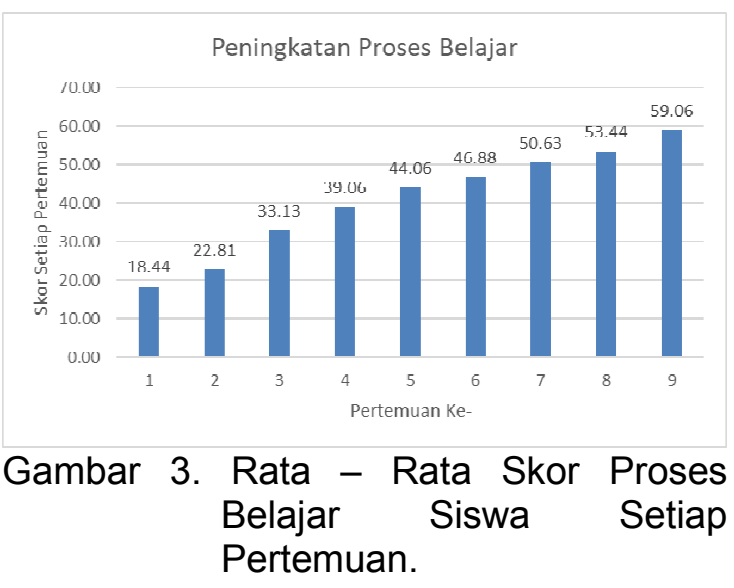

Ini menunjukkan adanya hubungan saling terkait antara minat belajar, prestasi belajar dengan proses belajar. Sehingga peningkatan minat dan prestasi belajar dibarengi juga dengan peningkatan proses belajar.

\section{PEMBAHASAN}

Berdasarkan hasil penelitian yang sudah dipaparkan sebelumnya, terlihat bahwa prestasi belajar matematika siswa kelas VIIID SMP Negeri 2 Sawan yang ditinjau dari rata-rata skor tes prestasi belajar sudah memenuhi indikator keberhasilan. Hasil penelitian ini menunjukkan bahwa rata-rata skor prestasi belajar pada siklus I adalah 61,93, rata-rata skor pada siklus II adalah 69,67, dan rata-rata skor prestasi belajar siswa pada siklus III adalah 77,66.

Dilihat dari rata-rata skor prestasi belajar siswa pada siklus I, siklus II, dan siklus III, rata-rata skor prestasi belajar siswa mengalami peningkatan dan sudah memenuhi indikator keberhasilan penelitian yang sudah ditetapkan, yakni rata-rata skor siswa minimal berada pada KKM 70. Selain itu, pada siklus III sudah tidak ada lagi siswa yang skornya berada dibawah KKM. Tentu hal ini tidak terlepas dari pelaksanaan pembelajaran matematika dengan menerapkan pembelajaran matematika berbantuan video tutorial.

Pada pelaksanaan siklus I, terjadi peningkatan prestasi belajar siswa dari refleksi awal. Pada refleksi awal, rata-rata skor prestasi belajar siswa masih berada di bawah KKM , sedangkan setelah diberikan tindakan, sudah menunjukkan adanya peningkatan cukup signifikan yakni sebesar 34,39 dari refleksi awal, namun belum memenuhi indikator keberhasilan, sehingga perlu untuk ditingkatkan lagi dengan melakukan perbaikan-perbaikan yang menjadi kendala selama pelaksanaan tindakan siklus I seperti yang telah dipaparkan pada refleksi siklus I.

Selanjutnya, dengan melakukan perbaikan-perbaikan pada siklus II, kembali terjadi peningkatan prestasi belajar siswa, di mana peningkatan prestasi belajar siswa dari siklus I ke siklus II meningkat sebesar 7,74. Peningkatan ini terjadi karena pada siklus II pembelajaran yang dilaksanakan sudah lebih baik dari siklus I. Siswa sudah dapat menyesuaikan diri dalam mengikuti pembelajaran dengan video tutorial, sehingga siswa tidak enggan lagi. Selain itu sebagian besar siswa sudah mengerjakan LKS sesuai dengan kemampuannya sendiri sesuai apa yang dipelajari di video tutorial. Adanya kemajuan-kemajuan pada siklus II tidak terlepas dari peran guru yang selalu memotivasi siswa agar lebih percaya diri akan kemampuannya sendiri ketika mengerjakan LKS. Siswa juga sudah mampu menyampaikan gagasannya, baik ketika berperan sebagai problem solver, maupun ketika berperan sebagai listener.

Akibatnya, siswa mampu mengkomunikasikan ide-ide matematisnya, baik secara lisan maupun tertulis, Hal ini disebabkan karena guru selalu menuntun dan memotivasi siswa yang masih bingung akan tugasnya pada tahap ini. Dengan demikian, dapat dikatakan bahwa pembelajaran pada siklus II sudah lebih baik dibandingkan dengan siklus I. Walaupun rata-rata skor prestasi belajar siswa pada siklus II mengalami peningkatan, masih belum memenuhi indikator keberhasilan, karena masih ada siswa yang skornya berada di bawah KKM, sehingga diperlukan perbaikan-perbaikan terhadap pembelajaran untuk ditingkatkan pada siklus III.

Selanjutnya, dengan melakukan beberapa upaya perbaikan pelaksanaan 
tindakan sesuai dengan yang sudah dijelaskan pada refleksi siklus II dengan tetap memperhatikan tindakan sebelumnya yang sudah baik, ternyata hasil tindakan siklus III memberikan hasil yang lebih baik daripada siklus II, di mana terjadi peningkatan sebesar 7,99 . Selain itu, skor siswa pada siklus III sudah tidak ada lagi yang berada di bawah KKM, sehingga hasil yang diperoleh pada siklus III sudah memenuhi indikator keberhasilan, yakni skor siswa memenuhi KKM 70 dan $75 \%$ skor siswa minimal berada pada kategori tuntas. Tercapainya hasil yang baik pada siklus III disebabkan karena pembelajaran pada siklus III sudah jauh lebih baik dan secara umum pembelajaran sudah berjalan sesuai skenario pembelajaran yang direncanakan. Sebagian besar siswa sudah mampu mengikuti setiap tahapan pembelajaran dengan berbantuan video tutorial.

Selain itu, kondisi pembelajaran semakin kondusif dan siswa terlihat termotivasi untuk mengikuti pembelajaran. Hal ini terlihat dari antusiasme yang ditunjukkan oleh setiap siswa selama pembelajaran berlangsung. Sehingga minat belajar siswa juga mengalami peningkatan pada setiap siklusnya. Pada siklus I rata - rata minat belajar siswa sebesar 59,28 ini menunjukkan minat belajar siswa sudah tinggi. Pada siklus II terjadi peningkatan sebesar 5,43 menjadi 64,71 pada tahap ini minat belajar siswa masuk pada kategori sangat tinggi. Siklus III juga mengalami peningkatan yakni sebesar 1,28 meskipun tidak sebesar siklus sebelumnya namun pada kategori ini minat belajar siswa sudah sangat tinggi dan mencapai indikator keberhasilan.

Pemaparan di atas sesuai dengan Kemp \& Dayton (dalam Arsyad, 2011) bahwa banyak keuntungan penggunaan media pembelajaran. Mereka mengemukakan beberapa hasil penelitian yang menunjukkan dampak positif dari penggunaan media sebagai bagian penting pembelajaran di kelas, antara lain

1. Penyampaian pesan menjadi lebih baku karena setiap pelajar yang melihat atau mendengar penyajian melalui media menerima pesan yang sama.

2. Pembelajaran bisa lebih menarik karena dapat membuat siswa terjaga dan memperhatikan.

3. Pembelajaran menjadi lebih interaktif dengan diterapkannya teori belajar dan prinsip-prinsip psikologis yang diterima dalam hal partisipasi siswa, umpan balik, dan penguatan.

4. Lama waktu pembelajaran yang diperlukan dapat dipersingkat karena kebanyakan media hanya memerlukan waktu singkat untuk mengantarkan pesan/ isi pelajaran dalam jumlah yang cukup banyak.

5. Kualitas hasil belajar dapat ditingkatkan apabila media pembelajaran dapat mengkomunikasikan pengetahuan dengan cara yang baik, spesifik, dan jelas.

6. Pembelajaran dapat diberikan kapan dan di mana diperlukan.

7. Sikap positif siswa terhadap apa yang mereka pelajari dapat ditingkatkan.

8. Peran guru dapat berubah ke arah yang lebih positif, beban guru untuk penjelasan yang berulang-ulang mengenai isi pelajaran dapat dikurangi bahkan dihilangkan sehingga guru dapat memusatkan perhatian kepada aspek penting lain dalam proses belajar mengajar.

Berdasarkan hasil yang diperoleh, penerapan pembelajaran matematika berbantuan video tutorial ini secara umum sudah mampu meningkatkan kemampuan prestasi belajar siswa Kelas VIIID SMP Negeri 2 Sawan. Dengan berbantuan video tutorial, penerapan pembelajaran matematika siswa menjadi lebih efektif. Selain itu, siswa juga memberikan respon yang positif terhadap penerapan pembelajaran matematika berbantuan video tutorial ini. Minat belajar siswa pun meningkat sesuai dengan data yang diperoleh di atas, hal ini terlihat dari sebagian besar siswa yang merasa senang dan mudah dalam memahami materi pelajaran dan juga tampak aktif dalam mengikuti pembelajaran. Sehingga 
semua proses pembelajaran mengalami peningkatan pada setiap pertemuan.

\section{SIMPULAN DAN SARAN SIMPULAN}

Berdasarkan hasil analisis data dan pembahasan hasil penelitian, dapat disimpulkan bahwa penerapan pembelajaran matematika berbantuan video tutorial dapat meningkatkan minat dan prestasi belajar siswa kelas VIIID SMP Negeri 2 Sawan.

1. Penggunaan video tutorial membantu mengefektifkan proses belajar di kelas hal ini terlihat dari data yang diperoleh pada setiap pertemuan mengalami peningkatan. Dan peningkatan proses belajar ini berpengaruh dalam meningkatkan minat dan prestasi belajar siswa.

2. Peningkatan prestasi belajar siswa disebabkan karena pada setiap tahapan model pembelajaran video tutorial, siswa dilatih untuk mengembangkan kemampuannya dalam menyelesaikan soal latihan yang diberikan. Dari hasil tes prestasi belajar rata-rata skor kemampuan prestasi belajar siswa juga mengalami peningkatan sebesar 69,67 pada siklus II menjadi 77,66 pada siklus III dan pada siklus III sudah mencapai indikator keberhasilan yang sudah ditetapkan.

3. Video tutorial mampu meningkatkan minat siswa terhadap pembelajaran di kelas karena pembelajaran menjadi lebih menarik dan inovatif sehingga dapat membuat siswa terjaga dan memperhatikan. Hal ini juga diperkuat dengan hasil tes minat sangat positif, yaitu sebesar 66,53.

Dengan demikian minat dan prestasi belajar siswa dapat ditingkatkan melalui penerapan pembelajaran berbantuan video tutorial. Proses belajar yang meningkat juga sangat mempengaruhi keberhasilan pembelajaran matematika berbantuan video tutorial dalam meningkatkan minat dan prestasi belajar matematika siswa kelas VIIID SMP Negeri 2 Sawan.

\section{SARAN}

Berdasarkan hasil penelitian dan temuan-temuan dalam penelitian tindakan kelas ini, dapat diajukan beberapa saran sebagai berikut: 1) Dalam rangka mengoptimalkan pembelajaran matematika, penerapan pembelajaran matematika berbantuan video tutorial layak untuk dipertimbangkan; 2) Pembaca yang berminat untuk melaksanakan penelitian lebih lanjut mengenai pembelajaran matematika berbantuan video tutorial diharapkan agar memperhatikan kendala-kendala yang dialami selama pelaksanaan penelitian sebagai bahan pertimbangan untuk perbaikan dan penyempurnaan pelaksanaan penelitian.

\section{DAFTAR PUSTAKA}

Arikunto, S. 2012. Dasar - dasar evaluasi pendidikan (edisi kedua). Jakarta : Bumi Aksara

Arsyad, A. 2005. Media Pembelajaran. Jakarta : PT RajaGrifindo Persada

Candiasa, I. M. 2010a. Pengujian Instrumen Penelitian Disertai Aplikasi ITEMAN dan BIGSTEPS. Singaraja: Unit Penerbitan Universitas Pendidikan Ganesha.

I. M. 2010b. Statistik Univariat dan Bivariat Disertai Aplikasi SPSS. Unit Penerbitan Universitas Pendidikan Ganesha.

Depdiknas, 2008. Kamus Besar Bahasa Indonesia Edisi Keempat. Yogyakarta : Gramedia Pustaka Utama

Sudiarta, I. G. P, \& Sadra I. W.. 2016. Pengaruh Model Blended Learning Berbantuan Video Animasi Terhadap Kemampuan Pemecahan Masalah Dan Pemahaman Konsep Siswa. Jurnal Pendidikan dan Pengajaran 49 (No.2), 48-58. 
Jurnal Pendidikan Matematika Undiksha, Volume IX No 2, Agustus 2018 e-ISNN:2599-2600; p-ISNN: 2613-9677

Sudiarta, I. G. P. 2013. Kontribusi Bakat Numerik, Kecerdasan Spasial, Dan Kecerdasan Logis Matematis Terhadap Prestasi Belajar Matematika Siswa Sd Negeri Di Kabupaten Buleleng. E-Journal Program Pascasarjana Universitas Pendidikan Ganesha Program Studi Matematika (Volume 2 Tahun 2013).

2007. Mencermati Paradigma Baru Dalam Penelitian Pendidikan Matematika. Jurnal Pendidikan dan Pengajaran UNDIKSHA Singaraja. 